Vita Meylani, Rinaldi Rizal Putra. (2019). Analisis E.Coli Air Minum dalam Kemasan yang Beredar di Kota Tasikmalaya. Journal Bioeksperimen. Vol. 5 (2) Pp. 121-125. Doi: 10.23917/bioeksperimen.v5i2.2795

\title{
ANALISIS E. COLI PADA AIR MINUM DALAM KEMASAN YANG BEREDAR DI KOTA TASIKMALAYA
}

\author{
Vita Meylani*, Rinaldi Rizal Putra \\ Prodi. Pendidikan Biologi FKIP Universitas Siliwangi \\ *E-mail korespondensi: vibriovita@unsil.ac.id \\ Paper diterima : 28 Februari 2018, Paper publish : September 2019
}

\begin{abstract}
Drinking water is the main need of humans as living things. Over time, humans are more practical so that for drinking needs they prefer to use bottled drinking water or refill drinking water. The high demand for bottled water raises the number of drinking water companies that issue bottled drinking water products. However, the quality of bottled water still needs to be assessed because it is not through pasteurization or other processing. So the microbiological content remains to be investigated. This study aimed to determine the bacteriological content in bottled drinking water. This study uses the Most Probable Number (MPN) method to test its bacterial content and gamma ray radiation to test its radiosensitivity. The sample in this study was bottled drinking water of various brands circulating in the City of Tasikmalaya. Based on the research results obtained from 13 samples there is 1 sample containing E. coli which is code B1 with a total bacterial content of 7 cells per 100 $\mathrm{ml}$. So it can be concluded $L$ samples are known to contain E. coli as much as $1.9 \times 105$ cells per $\mathrm{ml}$.
\end{abstract}

Keywords: E. coli, MPN, drinking water, Tasikmalaya

\section{Pendahuluan}

Air merupakan kebutuhan utama makhluk hidup untuk memenuhi segala kebutuhannya sehari-hari. Air yang digunakan untuk keperluan sehari-hari seperti minum, memasak, mencuci dan lain-lain harus memenuhi persyaratan kesehatan. Di Indonesia, air untuk keperluan sehari-hari tersebut diatur dengan Peraturan Menteri Kesehatan No. 416 tahun 199 (Permenkes untuk air bersih, air kolam renang, dan air pemandian umum) dan Keputusan Menteri Kesehatan No 907 tahun 2012 (Kepmenkes untuk air minum). Selain itu, Peraturan Menteri Kesehatan Republik Indonesia Nomor 492/Menkes/Per/IV/2010 tentang Persyaratan Kualitas Air Minum menytakan air minum dinyatakan aman bagi kesehatan apabila memenuhi persyaratn fisika, mikrobiologis, kimiawi dan radioaktif yang dimuat dalam parameter wajib dan parameter tambahan. Oleh karena itu, apabila air minum yang dikonsumsi masyarakat tidak sesuai dengan kriteria tersebut makan air tersebut tidak layak konsumsi.
Air minum dalam kemasan (AMDK) adalah air baku yang telah melalui sebuah proses sterilisasi, dikemas, dan aman untuk diminum mencakup air mineral dan air demineral. Beberapa tahun terakhir ini penjualan air minum dalam kemasan (AMDK) di Indonesia berkembang sangat pesat, sehingga banyak terjadi persaingan bagaimana memproduksi air minum yang layak dikonsumsi masyarakat. Ada yang menyebut air minum mineral, ada pula air minum murni, dengan kualitas yang bermacam-macam pula. Hal tersebut ternyata memunculkan perbedaan pendapat air mineral dan air murni dikalangan para ahli dan produsen air minum.

Saat ini air minum dalam kemasan (AMDK) masih mendominasi pangsa pasar minuman ringan di Indonesia dengan persentase sebesar $(84,1 \%)$ kemudian diikuti oleh minuman teh cepat saji $(8,9 \%)$, minuman berkarbonasi $(3,5 \%)$ dan minuman ringan lainnya $(3,5 \%)$. Data tersebut tidak terlepas dari gaya hidup yang serba praktis belakang ini sehingga mendorong munculnya perusahaan air minum baru untuk memenuhi kebutuhan pasar 
dengan menawarkan harga yang relatif murah tanpa memerhatikan kualitas air minum.

Kualitas standar air minum di Indonesia telah diatur menurut Standar Nasional Indonesia No. SNI 01-3553-2006 Departemen Perindustrian dan Perdagangan yang menyatakan bahwa batas maksimum total angka bakteri koliform adalah kurang dari 2 dalam $100 \mathrm{ml}$ air minum (Anonim, 2006). Bakteri koliform adalah bakteri yang umum digunakan sebagai indikator penentuan kualitas sanitasi makanan dan air. Koliform sebenarnya bukan penyebab dari penyakit-penyakit bawaan air, namun bakteri jenis ini mudah untuk dikultur dan keberadaannya dapat digunakan sebagai indikator keberadaan bakteri pathogen (Servais et al., 2007) termasuk E. coli. Oleh karena itu, keberadaan bakteri tersebut dapat menjadi indicator kualitas suatu air minum.

Berdasarkan uraian tersebut, maka perlu diadakan penelitian mengenai Analisis Kandungan dan Radiosensitivitas Escherichia coli pada Air Minum Dalam Kemasan yang Beredar di Kota Tasikmalaya 2017 dengan tujuan melindungi konsumen dari hal-hal yang tidak diinginkan dari isolat bakteri $E$. coli yang diperoleh dari air minum dalam kemasan.

\section{Metode Penelitian}

Subjek penelitian ini adalah air minuman dalam kemasan berbagai merk yang beredar di sekitar Kota Tasikmalaya. Metode penelitian ini adalah metode kuantutatif menggunakan teknik MPN dan radiasi sinar gamma. Sampel air minum dalam kemasan diambil secara acak di sekitar Kota Tasikmalaya. Berikut ini adalah tahapan penelitian yang akan dilakukan:

\section{Pengambilan Sampel}

Sampel penelitian diambil secara acak dari berbagai pasar dan toko yang menjual air minum dalam kemasan di sekitar Kota Tasikmalaya.

\section{Penghitungan Total Bakteri E. coli}

Sampel air minum dalam kemasan kemudain dihitung total bakteri $E$. coli menggunakan metode MPN yang terdiri dari :
- Uji penduga (presumptive test)

Pada tahap ini spesimen cair ditanam pada 5 tabung Lactose Broth Triple Strenght $(5 \mathrm{ml})$ masing-masing 10 $\mathrm{ml}$, satu tabung Lactose Broth Triple Strenght $(10 \mathrm{ml})$ masing-masing 1 $\mathrm{ml}$, satu tabung Lactose Broth Triple Strenght $(10 \mathrm{ml})$ masing-masing $0,1 \mathrm{ml}$. Tabung-tabung tersebut di inkubasi pada suhu $37^{\otimes} \mathrm{C}$ selama 48 jam. Tabung-tabung yang menghasilkan gas dilanjutkan dengan uji penegasan.

- Uji penegasan (confirmed test) Pada tahap ini tabung-tabung Lactose Broth Triple pada uji penduga yang mengahsilkan gas diambil sedikit dengan mencelupkan ose ke dalam dalamnya kemudian dicelupkan kembali ke dalam tabung Brilliant Green Lactose Bile Broth, kemudian diinkubasi pada suhu $37^{\otimes} \mathrm{C}$ selama 48 jam. Tabung-tabung yang menghasilkan gas dicatat dan dicocokkan dengan tabel MPN untuk menentukan jumlah bakteri Coliform yang terkandung di dalam sampel.

\section{- Uji pelengkap (completed test)}

Pada tahap ini tabung Brilliant Green Lactose Bile Broth yang menghasilkan gas dicelupkan dengan ose setipis mungkin, kemudian ditanam padaagar EMB dan diinkubasi dalam inkubator $37^{\circledR} \mathrm{C}$ selama 24 jam. Keberadaan $E$. coli ditandain dengan terbentuknya koloni bakteri yang rata dan mengkilat (merah kehijauan metalik). Koloni suspect E. coli dilakukan uji biokimia. Ose digoreskan pada koloni suspect $E$. coli kemudian ditanam pada tabungtabung untuk uji biokimia (glukosa, laktosa, manitol, maltose, sukrosa, SIM, agar citrat). Tabung-tabung tersebut kemudian diinkubasi di dalam inkubator $37^{\otimes} \mathrm{C}$ selama 24 jam. Positif E. coli apabila pada uji biokomia didapatkan hasil uji glukosa $(+)$, laktosa $(+)$, manitol $(+)$, maltose 
$(+)$, sukrosa $( \pm), \mathrm{H}_{2} \mathrm{~S}(-)$, indol $(+)$, motilitas $( \pm)$, dan sitrat $(+)$.

\section{Analisis Data}

Teknik analisis data digunakan secara kuantitatif dilakukan dengan cara menghitung rerata jumlah koloni bakteri $E$. coli yang terkandung dalam air minum dalam kemasan masing-masing sampel.

Data yag diperoleh baik hasil perhitungan MPN koloni bakteri E. coli maupun hasil radiasi sinar gamma dianalisis untuk memperoleh simpulan penelitian.

\section{Teknik Pengumpulan Data penelitian}

Teknik pengumpulan data yang akan dilakukan pada penelitian ini adalah melalui pengamatan secara kuantitatif dengan cara menghitung jumlah koloni bakteri $E$. coli yang terkandung dalam air minum dalam kemasan menggunakan metode MPN.

\section{Hasil Dan Pembahasan}

1. Analisis Kandung $E$. coli dalam Air Mineral dalam Kemasan yang Beredar di Kota Tasikmalaya

Sampel dalam penelitian adalah 13 merk air mineral yang beredar di Kota Tasikmalaya yaitu : i) Aqua, ii) Ades, iii) Ron 88, iv) Le mineral, v) Club, vi) Viro, vii) Nestle, viii) Prim-a, ix) Indomaret, $x$ ) Air cup, xi) Tirta, xii) Yasmin, dan xiii) Sodft rider yang selanjutnya diberi kode A, B, C, D, E, F, G, H, I, J, K, L, dan M. Tiga belas sampel air mineral tersebut diperoleh dari berbagai warung dan pasar yang ada di Kota Tasikmalaya. Sampel tesebut kemudian diuji kandungan $E$. coli nya menggunakan teknik MPN.

Tahap pertama yang dilakukan pada penelitian ini yaitu uji praduga dengan menggunakan media lactose broth yang merupakan media untuk mendeteksi adanya bakteri koliform. Hasil positif pada uji praduga ini ditandai dengan terbentuknya gas dalam tabung durham yang dapat dilihat pada Gambar 1 berikut ini.

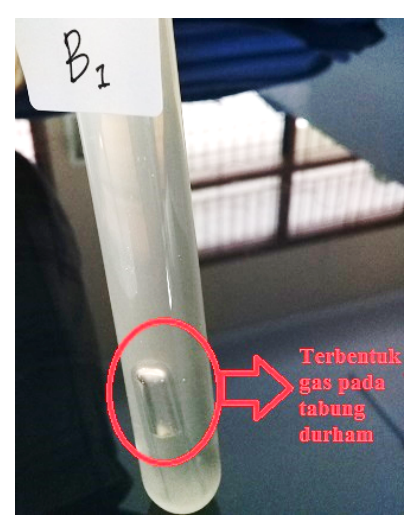

Gambar 1. Hasil Positif Pada Media Lactose Broth

Tabung yang menunjukkan hasil positif diuji lebih lanjut dengan uji penegas menggunakan media Brilliant Green Lactose Bile Broth (BGLB). Tabung dinyatakan positif bila di dalam tabung durham terbentuk gas, seperti pada Gambar 2 berikut ini.

Uji pelengkap ini dilakukan untuk melihat koloni bakteri koliform pada tabung yang positif dengan cara menginokulasikan sampel air minum isi ulang tersebut pada media agar yaitu Eosin Methylen Blue kemudian diinkubasi selama 24 jam dengan suhu $37^{\circ} \mathrm{C}$. Berikut ini merupakan media EMB yang terdapat bakteri koliform.

Warna merah muda dan tidak memiliki kilap logam pada media Eosin Methylen Blue (Gambar 3) diduga adanya bakteri Pseudomonas Aeruginosa yang merupakan salah satu kelompok bakteri koliform yang mampu memfermentasikan laktosa sedangkan untuk bakteri yang tidak memfermentasikan laktosa koloninya tidak berwarna.

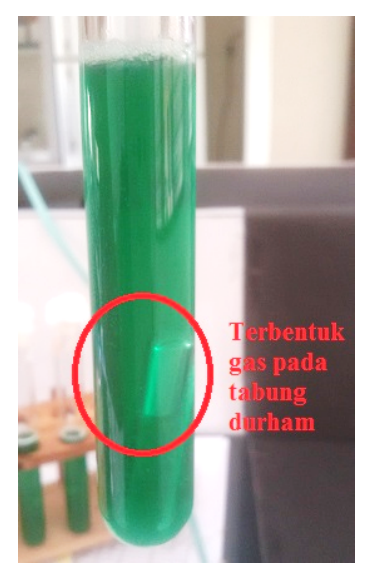

Gambar 2. Tabung Positif pada Media Brilliant Green Lactose Bile

Vita Meylani, Rinaldi Rizal Putra-123 


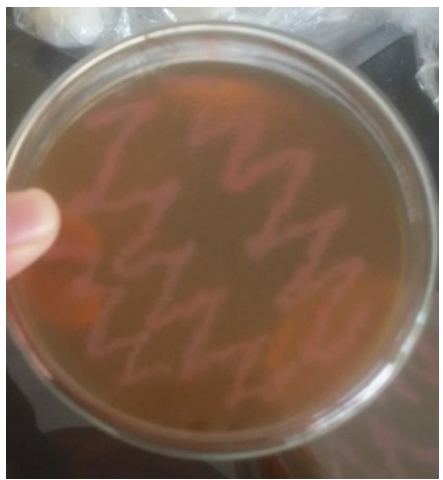

Gambar 3. Media Eosin Methylen Blue yang Terdapat Bakteri Koliform

Hasil positif dari uji MPN tersebut kemudian dicocokan dengan tabel MPN seri 3 tabung (Tabel 1)

Tabel 1. Hasil Analisis E. coli pada Sampel Menggunakan Metode MPN

\begin{tabular}{ccccc}
\hline \multirow{2}{*}{ Sampel } & \multicolumn{3}{c}{ MPN Seri 3 tabung } & $\begin{array}{c}\text { MPN } \\
\text { (per 100 } \\
\text { ml) }\end{array}$ \\
\hline A & 0 & 0 & 0 & 0 \\
B & 1 & 1 & 0 & 7 \\
C & 0 & 0 & 0 & 0 \\
\hline
\end{tabular}

Berdasarkan 3 sampel air minum isi ulang yang diuji 1 sampel tidak memenuhi persyaratan mikrobilogis bakteri koliform yang ditetapkan dalam Peraturan Menteri Kesehatan Republik Indonesia No. 492/MENKES/Per/IV/2010 yaitu kadar maksimum bakteri koliform 0 per $100 \mathrm{ml}$ air (Tabel 1). Pada pemeriksaan sampel air minum isi ulang ini didapatkan satu sampel yang mengandung bakteri koliform yaitu sampel B dengan 7 per $100 \mathrm{ml}$ air sedangkan sampel air A dan $C$ itu tidak terdapat bakteri koliform.

Adanya bakteri koliform di dalam air minum isi ulang menunjukan kemungkinan adanya kontaminasi serta adanya mikroba yang bersifat enteropatogenik yang dapat mengganggu kesehatan.

Faktor yang mungkin menyebabkan hasil positif dari uji praduga MPN ini adalah terjadinya kontaminasi air minum isi ulang pada proses pengolahannya antara lain penampungan air baku, desinfeksi maupun penyaringan pada depot yang kurang maksimal Peralatan sterilisasi merupakan salah satu penentu kualitas air minum yang akan dihasilkan oleh usaha depot air minum, sebab jika penggunaan alat sterilisasi yang tidak dalam masa pakai, maka alat sterilisasi tersebut tidak dapat membebaskan air minum dari mikroorganisme yang terdapat dalam air, selain itu, sanitasi dan higienitas dari depot air minum isi ulang itu sendiri dapat mempengaruhi hasil uji MPN diantaranya seperti:

a. Lamanya waktu penyimpanan air dalam tempat penampungan sehingga mempengaruhi kualitas sumber air baku yang digunakan;

b. Adanya kontaminasi selama memasukkan air ke dalam tangki pengangkutan;

c. Tempat penampungan kurang bersih;

d. Proses pengolahan yang kurang optimal;

e. Kebersihan lingkungan; dan

f. Adanya kontaminasi dari galon yang tidak disterilisasi.

Jadi, sanitasi yang buruk serta higientitas yang rendah dapat menyebabkan terjadinya kontaminasi. Permasalahan ini perlu ditanggulangi dengan cara meminimalisasi kemungkinan kontaminasi bakteri. Proses pengolahan air minum dilakukan dengan memperhatikan air baku, kebersihan operator, penanganan terhadap wadah pembeli dan kondisi depot. Pengetahuan operator depot air minum tentang kebersihan tentu juga akan mempengaruhi kualitas air yang dihasilkan. hanya sebagian kecil penjual sekaligus operator pada depot air minum yang mengerti betul arti kebersihan baik pada tempat proses air, lingkungan sekitar, pakaian yang dikenakan, dan kebersihan diri sendiri. Mencuci tangan adalah salah satu bentuk menjaga kebersihan diri sendiri untuk mengurangi kontaminasi, namun tidak satupun dari enam operator air minum pada depot air minum isi ulang di sekitar Universitas Siliwangi yang mencuci tangan sebelum menangani wadah pembeli. Karena penanganan terhadap wadah yang dibawa pembeli juga mempengaruhi kualitas air di dalamnya. "Walaupun air yang dihasilkan berkualitas, tapi jika tidak ada perhatian lebih terhadap wadah galon sebagai tempat untuk 
mengisikan maka akan memungkinkan terjadi kontaminasi terhadap air yang dihasilkan" (Depkes, 2003).

\section{Simpulan}

Dari 13 sampel penelitian yang diuji dengan teknik MPN pada tahap uji persumtif hamper semua sampel mengandung mikrobia tetapi yang mengandung gas hanya satu sampel yaitu L, kemudian sampel L dilanjutkan ke tahapan uji penegasan hasilnya maenghasilkan gas kemudian dilanjutkan ke tahapan uji pelengkap sampel L diketahui mengandung $E$. coli sebanyak $1.9 \times 10^{5}$ sel per ml.

\section{Daftar Pustaka}

Apriliana, Ety., Ramadhian, M. Ricky., \& Gapila, Meta. 2014. Bacteriological Quality of Refill Drinking Water at Refill Drinkung Water Depots in Bandar Lampung. JUKE 4 (7): 142146.

Bambang, Andrian G.,dkk.2014. Analisis Cemaran Bakteri Coliform Dan Identifikasi Eschericia Coli Pada Air Isi Ulang Dari Depot Di Kota Manado. Jurnal Ilmiah Farmasi - UNSRAT. Vol. 3 No.3.https://ejournal.unsrat.ac.id/index.php/pharmacon/article/viewFile/54 50/4957 (diakses tanggal 20 januari 2018)

Keputusan Menteri Kesehatan No. 907/MENKES/SK/VII/2002 Tentang SyaratSyarat dan Pengawasan Kualitas Air Minum PP RI Nomor 82 Tahun 2001 tentang Pengelolaan Kualitas Air dan Pengendalian Pencemaran Air, pasal 8 ayat 1 ditetapkan pengkelasan air sesuai dengan peruntukannya

Kusuma, S. A. F. 2010. Escherichia coli.http://pustaka.unpad.ac.id. Mahdiasanti, I. W. 2010. Uji Bakteriologi Air Minum Isi Ulang di Kota Batu Ditinjau dari Nilai MPN Coliform.Tahun 2010.Jurnal Healthy Science Vol. 1 No. 1: 50-62.

Nuria, Maulita Cut., Rosyid, Abdur., \& Sumantri. 2009. Uji Kandungan Bakteri Escherichia coli pada Air Minum Isi Ulang dari Depot Air Minum Isi Ulang si Kabupaten Rembang. Jurnal Ilmu-ilmu Pertanian. 5 (1):27-35.

Pradhika, E. I. 2011. Mikrobiologi Dasar-Metode MPN/ APM-Angka Paling Mungkin Bagian I. http://ekmon-saurusblogspot.com. (diakses tanggal 21 Januari 2017)

Pratama Sekedang, M. Iqbal., Manaf, Zakiah Heryawati., Darmawi., Jamin, Faisal., Abrar, Mahdi., \& Razali. 2016. Kontaminasi Bakteri Koliform pada Air Minum Isi Ulang di Desa Ilie Kecamatan Ulee Kareng Kota Banda Aceh. Jurnal Medika Veterinaria. 10(1):70-73.

Prayitno, Agus. 2009. Uji Bakteriologi Air Baku dan Air Siap Konsumsi dari PDAM Surakarta Ditinjau dari Jumlah Bakteri Coliform. Surakarta: Fakultas Keguruan dan Ilmu Pendidikan Universitas Muhammadiyah Surakarta.

Purbowarsito, H. 2011. Uji Bakteriologis Air Sumur di Kecamatan Semampir Surabaya.Skripsi. Tidak dierbitkan.Departemen Biologi Fakultas Sains dan teknologi Universitas Airlangga.

Rahmatullah, A. M. 2013. Studi Karakterisasi Bakteri Escherichia coli di Laboratorium Kesehatan Lumajang.Fakultas Matematika dan Ilmu Pengetahuan Alam Institut Teknologi Sepuluh Nopember. Soemirat, J. 2004. Kesehatan Lingkungan. Yogyakarta: Gadjah Mada University Press.

Widiyanti dan Ristiati, 2004.Analisis Kualitatif Bakteri Coliform pada Depo Air Minum Isi Ulang di Kota Singaraja Bali.Jurnal Ekologi Kesehatan Vol. 3 No. 1: 64-73. 